\title{
Influence of different dietary oil sources on performance and fatty acid profile of egg yolk in laying hens*
}

\author{
N. Ceylan ${ }^{1,3}$, I. Ciftçi', C. Mızrak², Z. Kahraman'² and H. Efiil ${ }^{2}$ \\ ${ }^{1}$ Ankara University, Faculty of Agriculture,Department of Animal Science \\ 06110 Ankara, Turkey \\ ${ }^{2}$ Ankara Poultry Research Institute \\ 06220 Ankara, Turkey
}

(Received 13 October 2010; revised version 16 February 2011; accepted 12 March 2011)

\begin{abstract}
Laying hens were fed diets containing sunflower, fish, linseed and rapeseed oil with 2 levels of inclusion (1.5 and 3.0\%) for 12 weeks. Egg production, egg weight, feed intake, feed conversion and liveweight were not significantly affected by the treatments. Hens receiving sunflower oil produced less intensively coloured egg yolks than those received other oils in their $\operatorname{diet}(\mathrm{P}<0.01)$. The fatty acid composition of the egg yolk was significantly $(\mathrm{P}<0.01)$ affected by the treatment, while cholesterol content was not influenced. There was a significant $(\mathrm{P}<0.05)$ interaction between fat source and the level of inclusion in the diet, linolenic acid content increased when hens were fed diet with $3 \%$ of linseed and rapeseed oil. Dietary fish oil significantly $(\mathrm{P}<0.01)$ increased the deposition of docosohexaenoic acid in the egg yolk. Sensory panelists scored as unacceptable those eggs from hens provided feed with $3 \%$ fish oil.
\end{abstract}

KEY WORDS: oil, egg yolk, cholesterol, fatty acid, performance, laying hen

\section{INTRODUCTION}

Eggs are rich in cholesterol (the average content ranges from 195 to $230 \mathrm{mg}$ per egg) that can negatively influence the development of atherosclerosis and for this

\footnotetext{
* Financial help by the Turkish Poultry Research Institute, Tavukçuluk Araştırma Enstitüsü

${ }^{3}$ Corresponding author: e-mail: ceylan@agri.ankara.edu.tr
} 
reason many people avoid of egg consumption. However, eggs are also very valuable source of proteins and contains many substances with biological function beyond basic nutrition (Mazalli et al., 2004; Laca et al., 2010; Liu et al., 2010). The eggs from hens provided standard feed are poor in linolenic acid (LNA; 18:3n-3), and does not contain eicosapentaenoic (EPA; 20:5n-3) and docosahexaenoic (DHA; 22:6n-3) fatty acids (Souza et al., 2008).

Modification of yolk fatty acids (FAs) through feeding hens with different fats has been reported previously. There is also evidence, that hens have a unique ability to deposit dietary lipid into the egg yolk, which makes the egg a potential source of polyunsaturated fatty acids (PUFAs) (Filardi et al., 2005). So during the past two decades have been demonstrated the desirable changes in the lipid profile of egg yolks by dietary supplemented with marine or oilseed oils (Van Elswyk, 1997; Milinsk et al., 2003; Cachaldora et al., 2006). It should be mentioned that the inclusion of n-3 PUFA promotes a qualitative change in the yolk FA profile and reducing the n-6/n-3 ratio to a more beneficial level with regards to the human nutritional needs (Simopoulos, 1998). The approved ratio is actually between 4:1 to 10:1 (Mazalli et al., 2004).

Fish oil is one of the best known sources of n-3 PUFA, as it is rich in EPA and DHA (Grashorn and Steinhilber, 1999). The inclusion of up to $60 \mathrm{~g} / \mathrm{kg}$ menhaden oil (containing $110 \mathrm{~g} / \mathrm{kg}$ EPA and $90 \mathrm{~g} / \mathrm{kg}$ DHA) in laying hen diets yielded eggs containing approximately 150-200 mg DHA/egg and 45-60 mg EPA/ egg (Gonzales-Esquera and Leeson, 2000). Similar results have been reported by Cachaldora et al. (2006). Linseed is one of the n-3 PUFA source, which has a high LNA content, while, sunflower seeds are rich in linoleic acid (LA; 18:2n-6) (Filardi et al., 2005).

Despite the positive effects of oils on the FA profile of eggs, the use of some oils in laying hen diets has raised the concerns related to sensory quality (Lawlor et al., 2010) there have been reported that eggs from hens offered linseed have a fishy odour or taste (Woods and Fearon, 2009) similar to that found in eggs from hens offered high level of fish oil in diet (above 1.5\% fish oil or $60 \mathrm{~g}$ micro encapsulated fish oil/kg diet) (Van Elswyk, 1997; Lawlor et al., 2010).

To our knowledge the literature about the comparison of the effect different level of various dietary oil sources on the egg's FA profile is scarce. The objective of the present research was to examine the relationship between different dietary oil sources and the egg yolk FA composition, interaction between different dietary oil sources with inclusion level and sensory quality of the hard-boiled eggs. 


\section{MATERIAL AND METHODS}

\section{Birds and housing}

Six hundred and forty ATE-K pullets, Brown egg layer from Ankara Poultry Research Institute, were obtained at 18 week of age. Birds were randomly distributed in four light-proof rooms each containing 8 floor pens (with the same management and environmental condition) and maintained under step-up ligthing schedule untill 38 wk of age. Birds received $15 \mathrm{~L}$ (lightness): $9 \mathrm{D}$ (darkness) from 18 until $20 \mathrm{wk}$ of age, $15.5 \mathrm{~L}: 8.5 \mathrm{D}$ until $21 \mathrm{wk}$ of age, and then $16 \mathrm{~L}: 8 \mathrm{D}$ from beginning at $22 \mathrm{wk}$ of age and then maintained at the schedule until the end of the trial. Hens were allotted to floor pens according to a block design in a $4 \times 2$ factorial arrangement of 8 treatments and four replications of 20 birds each one. Feed and water were provided ad libitum.

The experiment was performed in accordance with Ethical Commissions for Animal Welfare of the University of Ankara and the sensory analysis component of the research received ethical approval from our ethics board.

\section{Diets}

Eight dietary treatments including 4 different oil sources (sunflower oil, fish oil, linseed oil and rapeseed oil; briefly SO, FO, LO and RO, respectively) at 2 inclusion levels $(1.5$ and $3.0 \%)$ were studied. The diets were prepared as isonitrogenic and isocaloric including 17\% crude protein and 11.72 metabolizable energy ( $\mathrm{MJ} \mathrm{kg}^{-1}$ ) according to NRC (1994) nutrient recomendations for brown egg layers. Two diets differ in oil inclusion level were used as basal diets and their composition are shown in Table 1.

\section{Production parameters and sensory analysis}

Eggs were collected twice and recorded daily. Feed intake was measured weekly for each replicate. Eggs collected over $2 \mathrm{~d}$ at the end of each week were weighted. In eggs collected over $2 \mathrm{~d}$ at the end of each month albumen height, shell weight, shell thickness, yolk colour score (by using the DSM Yolk Colour Fan that previously called Roche Yolk Colour Fan) and specific gravity were measured. All birds were weighed at 22 and 34 wk of age.

Hard-boiled eggs without salt addition were sensory analysed according to Parpinello et al. (2006). 
Table 1. Ingredient composition and nutrient content of the basal diets, $\mathrm{g} \mathrm{kg}^{-1}$

\begin{tabular}{|c|c|c|}
\hline \multirow{2}{*}{ Item } & \multicolumn{2}{|c|}{ Oil inclusion level, $\%$} \\
\hline & 1.5 & 3.0 \\
\hline \multicolumn{3}{|l|}{ Ingredients, $\mathrm{g} \mathrm{kg}^{-1}$} \\
\hline maize & 608.92 & 520.28 \\
\hline soyabean meal & 256.80 & 252.27 \\
\hline oil & 15.00 & 30.00 \\
\hline wheat & 10.00 & 50.00 \\
\hline wheat bran & 5.00 & 40.00 \\
\hline calcium carbonate & 80.45 & 82.61 \\
\hline dicalcium phosphate & 13.10 & 13.67 \\
\hline $\mathrm{NaCl}$ & 3.50 & 3.50 \\
\hline DL-methionine & 1.26 & 1.45 \\
\hline vitamin premix $^{1}$ & 2.50 & 2.50 \\
\hline $\operatorname{mineral~}_{\text {premix }}{ }^{1}$ & 1.00 & 1.00 \\
\hline choline & 1.72 & 1.72 \\
\hline butylated hydroxtoluene & 0.75 & 1.00 \\
\hline \multicolumn{3}{|l|}{ Calculated analysis } \\
\hline $\mathrm{ME}, \mathrm{MJ} \mathrm{kg}^{-1}$ & 11.72 & 11.72 \\
\hline crude protein ${ }^{2}, \%$ & 17 & 17 \\
\hline crude fat ${ }^{2}, \%$ & 4.23 & 5.59 \\
\hline methionine + cystine, $\%$ & 0.68 & 0.70 \\
\hline lysine, $\%$ & 0.84 & 0.84 \\
\hline calcium, $\%$ & 3.46 & 3.45 \\
\hline available phosphorus, $\%$ & 0.35 & 0.37 \\
\hline \multicolumn{3}{|c|}{$\begin{array}{l}\text { supplied per kg of diet: IU: vit. A } 6.000 .000 \text {, cholecalciferol } 1.500 .000 ; \mathrm{mg} \text { : vit. E, } 15.000 \text {, } \\
\text { riboflavin } 3.000 \text {, pantothenic acid } 7.000 \text {, nicotinic acid } 25.000 \text {, folic acid } 500 \text {, Mn } 120.000 \text {, } \\
\mathrm{Zn} 80.000, \mathrm{Fe} 90.000, \mathrm{Cu} 15.000, \mathrm{I} 1.600, \text { Se } 500 \text {, Co } 600 \text { and calcium carbonate } 235.680 \text {; } \\
\mu \mathrm{g} \text { : vit. } \mathrm{B}_{12}, 15.000 ;{ }^{2} \text { analysed results }\end{array}$} \\
\hline
\end{tabular}

\section{Chemical analysis}

Ten random samples of eggs from each replicate were obtained for FA analysis when hens were $34 \mathrm{wk}$ of age. The FA profile of the experimental fats were also determined. Samples for FA profile of experimental fats and egg yolks were prepared as described by Ayerza and Coates (2000). The lipid profile was determined by means of gas chromatography (Shimadzu GC-14A, Shimadzu Corporation, 6048511 Kyoto, Japan) equipped with a BPX70 capillary column (SGE capillary column; length, $30 \mathrm{~m}$; I.D., $0.33 \mathrm{~mm} ; 70 \%$ cyanopropyl polysilphenylene-siloxane stationary phase), film, and a flame ionization detector. The operating conditions of the gas chromatograph were as follows: the initial temperature was $170^{\circ} \mathrm{C}$ for $8 \mathrm{~min}$, increasing by $3^{\circ} \mathrm{C} / \mathrm{min}$ to $180^{\circ} \mathrm{C}$, the temperature was increased by $5^{\circ} \mathrm{C} /$ min to $190^{\circ} \mathrm{C}$ and remained stable at final temperature for $25 \mathrm{~min}$, the injection temperature was $220^{\circ} \mathrm{C}$ and make up was $15 \mu 1 / \mathrm{sec}$. The FA percentage was 
integrated and then calculated by means of direct normalization of the peak areas. Each FA was identified in the form of a methyl ester by comparing the retention times with the standard acquired at Sigma Iterlab A.S. (Istanbul, Turkey).

Another 10 eggs were randomly collected from each replicate for determination of egg yolk cholesterol. Cholesterol analysis of egg yolks were done as described by Yang and Chen (2001) and Pie et al. (1990) method using thin-layer chromatography (TLC). The diets were also analysed for moisture, protein and crude fat according to AOAC (2005). All samples were analysed in duplicate.

\section{Statistical analysis}

Statistical analyses of data followed a randomized block design, with a factorial arrangement of $2 \times 4$, taking into consideration main effects of inclusion levels (1.5 and 3\%) and oil sources (FO, SO, LO and RO) with an equal number of 4 replicates for each treatment. The SAS programme (1996) was used for data analysing. When necessary mean separation was accomplished by using Duncan's multiple-range test a probability value of less than 0.05 was considered significant, unless otherwise noted. All percentage data were subjected to arcsine square root transformation (Steel and Torrie, 1960).

\section{RESULTS}

Table 2 shows the FA profile of fats used in present study. Fat sources and inclusion level have significant $(\mathrm{P}<0.01)$ effect on sensory quality of boiled eggs (Table 3). Increasing levels of FO over $1.5 \%$ significantly $(\mathrm{P}<0.01)$ impaired the appearance and odour of the eggs. Results belong to performance and egg quality selected parameters are shown in Table 4. Eggs laid by hens receiving higher levels of SO had higher DSM fan score than those fed other oil sources $(\mathrm{P}<0.01)$. Interaction between type and level of fat was also found significant $(\mathrm{P}<0.01)$ for egg yolk colour. Other egg quality parameters was not significantly changed by type and level of fat, except that by increasing inclusion level of fat, the number of spots increased in the yolk and albumen significantly $(\mathrm{P}<0.05)$.

The FA profile for the samples from eight treatments are presented in Table 5. FAs profile of the egg yolk were significantly $(\mathrm{P}<0.01)$ altered by the type and level of dietary fat, but cholesterol content of yolk was unchanged. The effect of fat source and inclusion level was significant $(\mathrm{P}<0.01)$ for egg yolk oleic acid (OA; C18:1n-9) concentration. Increasing level of fat inclusion caused more deposition of OA, LNA and DHA $(\mathrm{P}<0.01)$ in egg yolk, while arachidonic acid (AA; $\mathrm{C} 20: 4 \mathrm{n}-6)$ deposition declined $(\mathrm{P}<0.05)$. Monounsaturated 
Table 2. Analysed fatty acid profile of the fats used in the present study, $\%$ of total fatty acids

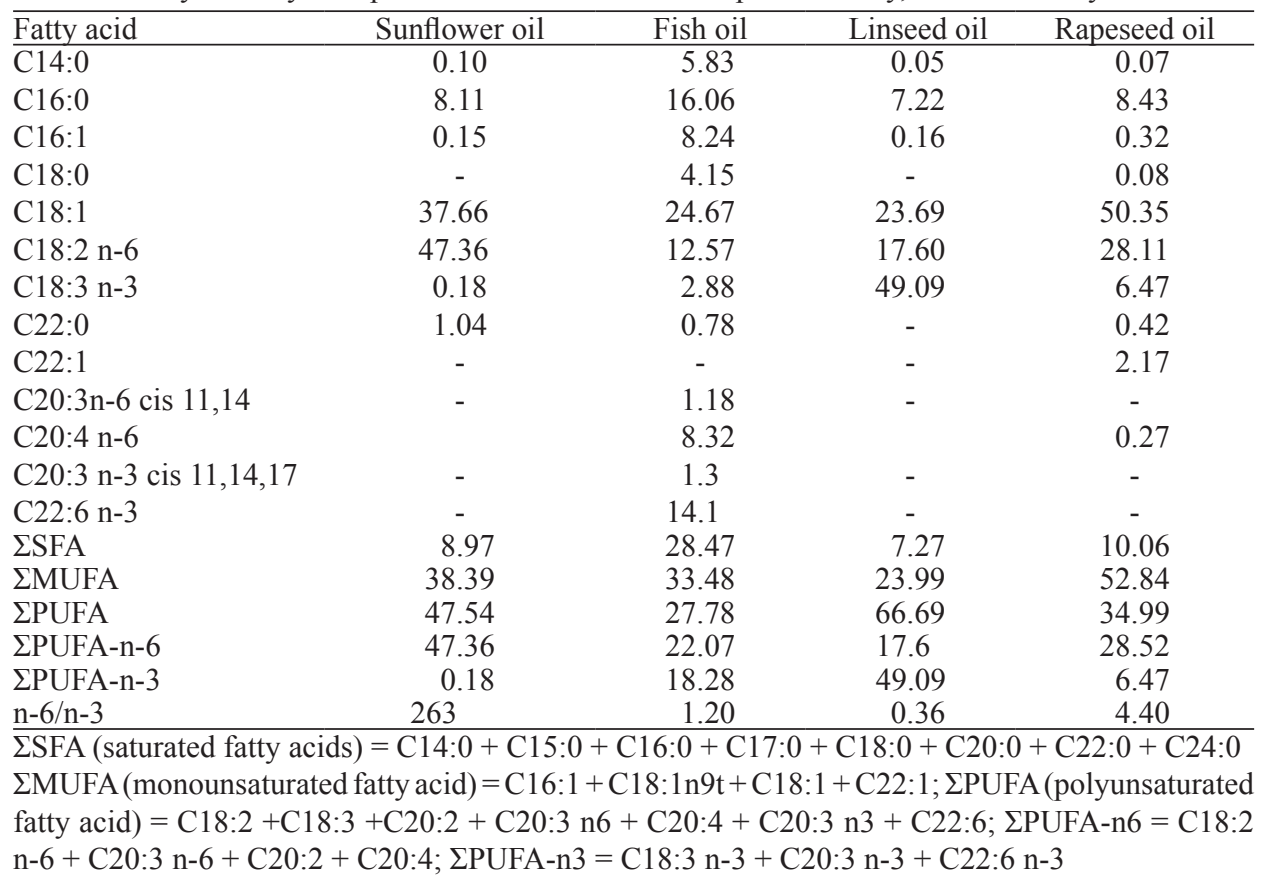

Table 3. Sensory analysis of boiled eggs ${ }^{1}$

\begin{tabular}{lccc}
\hline Item & Taste & Appearance & Odour \\
\hline Treatments, \% & & & \\
$\quad$ sunflower oil, 1.5 & 3.53 & $3.69^{\mathrm{b}}$ & $0.81^{\mathrm{a}}$ \\
sunflower oil, 3.0 & 3.22 & $3.78^{\mathrm{b}}$ & $0.75^{\mathrm{a}}$ \\
fish oil, 1.5 & 3.16 & $3.56^{\mathrm{b}}$ & $0.78^{\mathrm{a}}$ \\
fish oil, 3.0 & 2.84 & $2.44^{\mathrm{c}}$ & $0.47^{\mathrm{b}}$ \\
rapeseed oil, 1.5 & 3.63 & $3.94^{\mathrm{b}}$ & $0.75^{\mathrm{a}}$ \\
rapeseed oil, 3.0 & 3.18 & $3.63^{\mathrm{b}}$ & $0.84^{\mathrm{a}}$ \\
linseed oil, 1.5 & 3.97 & $4.56^{\mathrm{a}}$ & $0.90^{\mathrm{a}}$ \\
linseed oil, 3.0 & 3.56 & $3.61^{\mathrm{b}}$ & $0.84^{\mathrm{a}}$ \\
SEM & 0.148 & 0.178 & 0.06 \\
Main effects & & & \\
fat sources & & & \\
sunflower oil & $3.38^{\mathrm{a}}$ & $3.73^{\mathrm{b}}$ & $0.78^{\mathrm{a}}$ \\
fish oil & $3.00^{\mathrm{b}}$ & $3.00^{\mathrm{c}}$ & $0.63^{\mathrm{b}}$ \\
rapeseed oil & $3.40^{\mathrm{a}}$ & $3.78^{\mathrm{b}}$ & $0.80^{\mathrm{a}}$ \\
linseed oil & $3.67^{\mathrm{a}}$ & $4.01^{\mathrm{a}}$ & $0.87^{\mathrm{a}}$ \\
SEM & 0.12 & 0.10 & 0.05 \\
Inclusion level, \% & & & \\
1.5 & 3.57 & 3.94 & 0.81 \\
3.0 & 3.15 & 3.36 & 0.72 \\
SEM & 0.08 & 0.07 & 0.03 \\
Fat sources $\times$ inclusion level & NS* & 0.001 & 0.048 \\
\hline
\end{tabular}

${ }^{1}$ for taste and apparence: 5 - like very much, 1- dislike very much; for odour: 1 - feel no off flavour 0 - feel off flavour; *no significant 


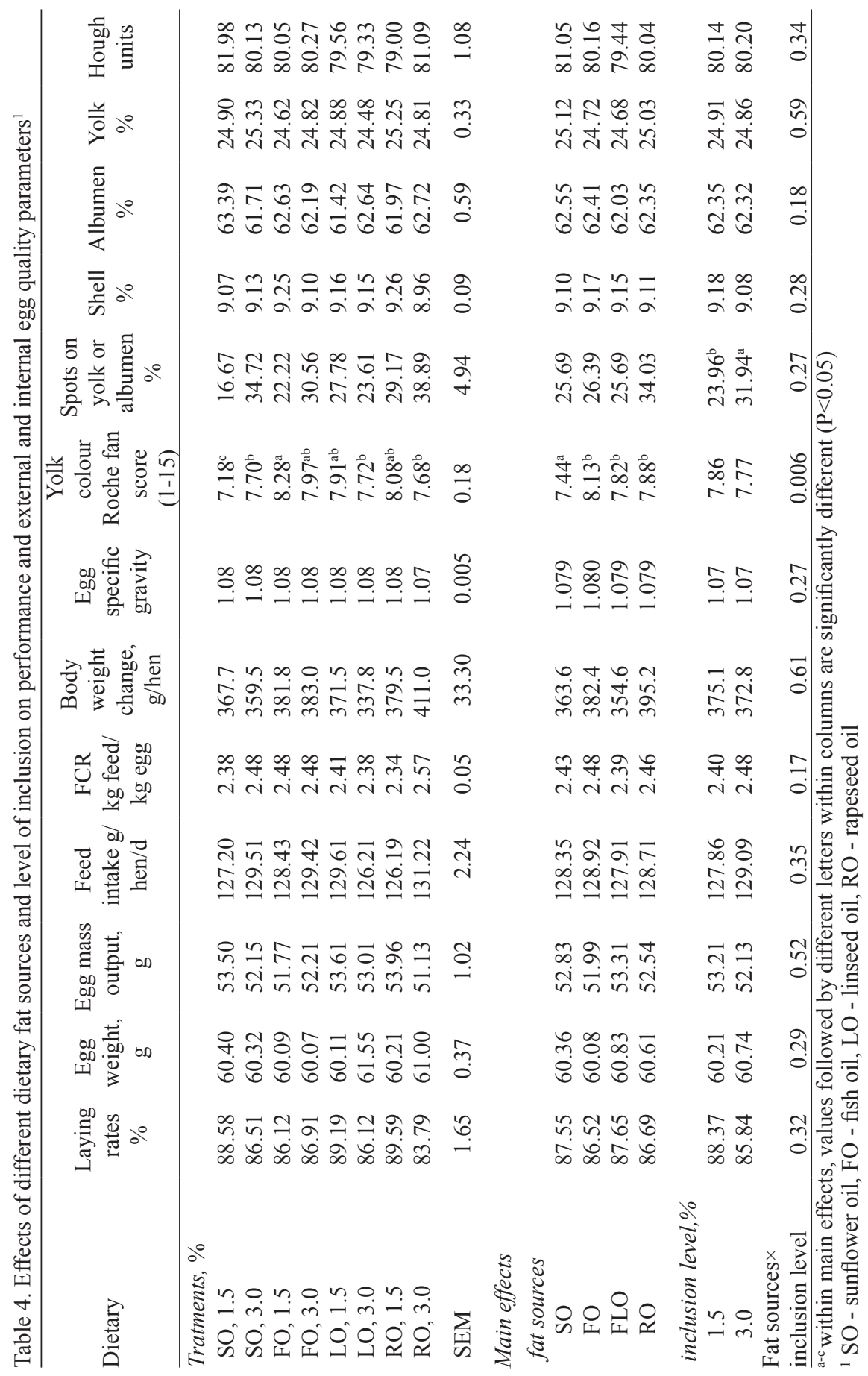




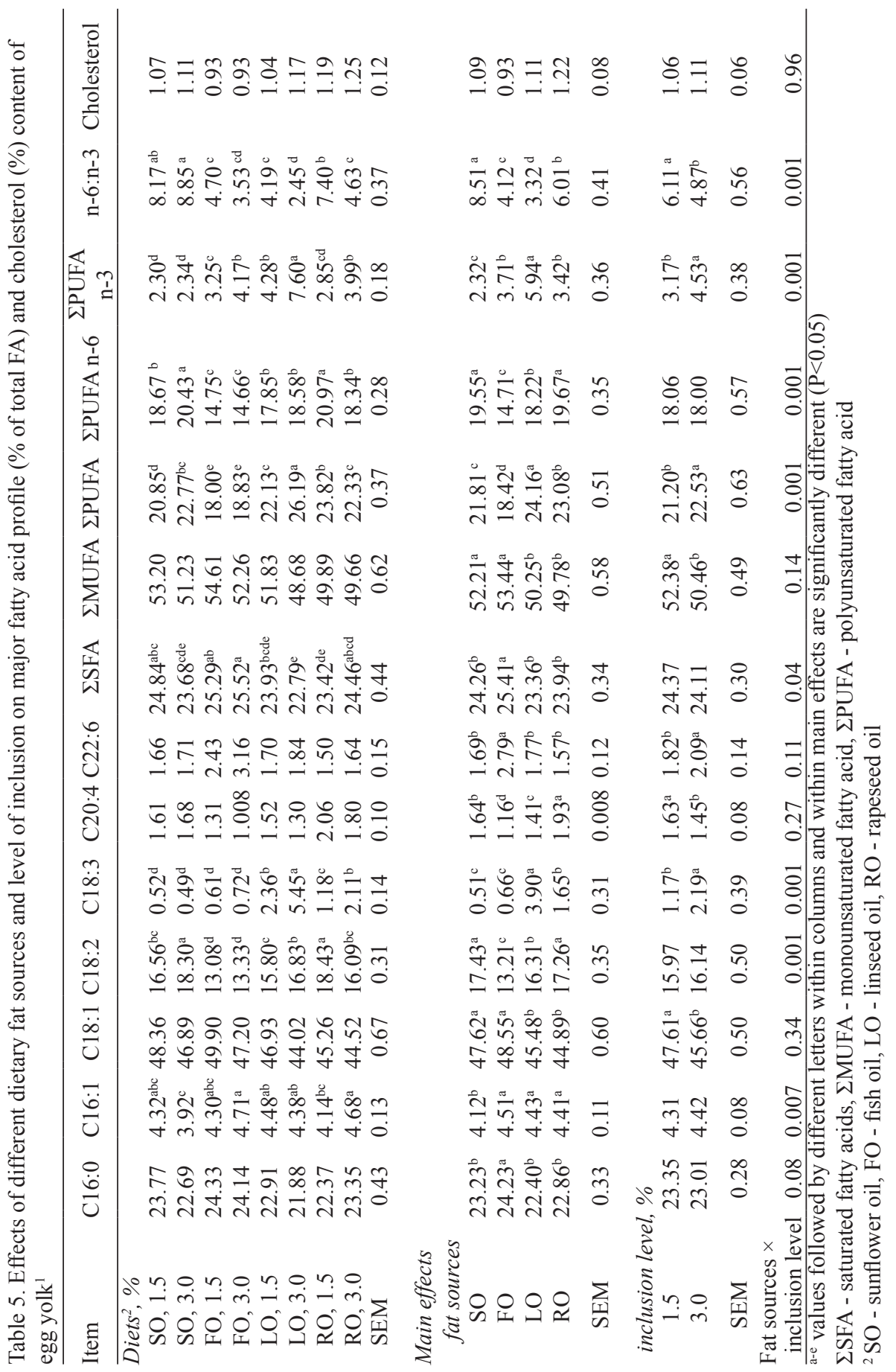


fatty acid (MUFA) deposition also decreased with higher inclusion level of fat, whereas PUFA amount increased significantly $(\mathrm{P}<0.01)$. A significant $(\mathrm{P}<0.01)$ interaction were found between oil level and source for deposition of LNA and LA in egg yolk. Hens fed with RO and LO deposited more C18:3 than those received $\mathrm{SO}$ and $\mathrm{FO}(\mathrm{P}<0.01)$. Adding of $\mathrm{FO}$ to layer diets have significantly $(\mathrm{P}<0.01)$ improved the deposition of 22:6 (n-3), in comparison to other oil sources. The concentration of $n-6$ PUFA in the egg yolk was reduced by increasing of SO and RO in the diets, while n-3 PUFA were higher when FO, LO and RO were supplemented. The lowest $n-6: n-3$ ratio was calculated in eggs laid by hens received $\mathrm{LO}(\mathrm{P}<0.01)$.

Feed cost did not show any significant difference between type of dietary fats, but increased by higher level of oil inclusion (data not shown).

\section{DISCUSSION}

No effects of dietary supplementing of FO, SO, LO and RO on the performance parameters were found in this study following 12 weeks period of experiment similarly as in studies of Atakisi et al. (2009). In Lawlor et al. (2010) study there were no significant differences due to dietary graded levels of microencapsulated FO for feed intake, egg production and egg weight. In the present study inclusion of 3\% FO to hen diets impared the sensory quality of the eggs. Kochler and Beprse (1975) first reported lower flavour ratings for eggs produced from hens fed 5\% fish meal, as well as a very slight off-flavour in eggs from hens on a $6 \%$ menhaden oil diet. Hammershoj (1995) found that taste and general impression were of lower grades for eggs from diets with 1.5 and 3\% FO compared with animal fat diets similarly as in present study. Scheideler et al. (1997) reported non significant difference in off-flavour and overall acceptability among scrambled eggs from $1.5 \%$ menhaden FO. The presence of fishy odour and fishy off-flavour might be related to several factors, including concentration of volatile compounds, presence of trimethylamine and lipid oxidation products (Van Elswyk et al., 1995; Parpinello et al., 2006). On the other hand Woods and Fearon (2009) reported that deodourization of fish oil removes ketones and benzene-containing compounds, thought to play a role in the formation of fishy odours.

Our results shows that enrichment of laying hens diet with n-3 PUFA does not affect the level of cholesterol in eggs, which is in accordance with the results of Cobos et al. (1995) on white and brown leghorns and da Silva et al. (2009) on quails. In contrast to our finding, in the study conducted by Atakisi et al. (2009) yolk cholesterol level was significantly lower $(\mathrm{P}<0.05)$ in the quails treated orally with FO capsules compared to the control group. It has been hypothesized that 
the inability to markedly reduce egg cholesterol levels is due to a physiological control mechanism that ultimately causes the cessation of egg production when yolk cholesterol deposition is inadequate for embryo survival (Milinsk et al., 2003).

According to the results of the present study, egg FA profile can be successfuly modified by manipulating layer diets by using appropriate supplemental fat (e.g., $\mathrm{SO}$, which contains high LA levels, increase egg content of this FA), as reported in earlier studies (Scheideler et al., 1998). Besides the importance of fat sources for modifying egg yolk FA profile, rate of deposition according to sources should be considered. In the current study the deposition efficiency of $\mathrm{C} 18: 3$ is higher for FO than other groups.

EPA was not present in egg yolk fatty acid profile, however, the results obtained for LA, LNA, AA and DHA are very close to Baucells et al. (2000) and Mazalli et al. (2004) reports. The amount of AA in egg yolk significantly $(\mathrm{P}<0.01)$ decreased by FO and this was concomitant with increasing the contents of DHA in egg yolk fat, so that n-6 FA was decreased and n-3 FA was increased similary as in Baucells et al. (2000) and Cachaldora et al. (2006). This phenomenon was probably due to the greater utilization of $\Delta-6$ desaturase in the n-3 FA with respect to the n- 6 pathway. As this enzyme acts in both routes (Ayerza and Coates, 2000), there is a competition among n-3 and n-6 FAs by decreased enzymes in their biosynthesis (Mazalli et al., 2004). Thus, the high level of LNA limits the synthesis of AA from LA, because LNA competes with LA by the same $\Delta-6$ desaturase enzymes. It was observed in this study, that the inclusion of FO decreased the synthesis of AA from LA. It should be mentioned that LNA metabolites, EPA and DHA also can reduce the production of AA. Thus, the increased ingestion of LNA in a diet results in significant decrease in the formation of AA (da Silva et al., 2009).

Source of fatty acids significiantly influenced $(\mathrm{P}<0.01)$ total PUFA's egg content as the group fed with $3 \%$ LO had the highest total PUFA. This may be explained by the high PUFA content in LO. These results are consistent with the findings of Mazalli et al. (2004), who observed an increase in PUFA egg percentage when evaluating diets containing 3\% SO or LO. PUFA ( $n-6$ and $n-3$ series) in the diet are more effective in reducing MUFA than saturated acids effected in eggs through the inhibition of $\Delta-9$ desaturase enzyme activity on the production of OA (Mazalli et al., 2004).

Nutritional quality can be assessed by the ratios LNA:LA and n-6/n-3 FA. In the current study SO effected in the highest n-6/n-3 ratio in comparison with the other oil sources. Souza et al. (2008) reported that the supplementation of diets with LO increased $(\mathrm{P}<0.05)$ the unsaturated to saturated FA ratio in the egg yolk and they showed a linear effect of dietary linseed oil inclusion level on LNA:LA and $n-6 / n 3$ ratios $(P<0.01)$. LNA can be desaturated and elongated in poultry liver 
to form DHA. Thus, when DHA is not directly supplied through diet, the LNA present in large amount in linseed become the DHA precursor (da Silva et al., 2009). FO, in general, is easily susceptible to oxidation (Frankel, 1984), while LO is fairly resistant to oxidation (Aymond and Van Elswyk, 1995) therefore, as the FO and LO can decrease n-6/n-3 ratio similarly to 4.12 vs 3.32 , respectively, if it should be chosen between FO and LO, using LO instead of FO with less risk to oxidation and undesirable changes in egg quality (appearance and odour) is possible.

\section{CONCLUSIONS}

It can be concluded that fatty acid profile of the egg can be modified by using supplemental fats rich in n-3 fatty acids. Cholesterol content of egg yolk can not be changed significant amounts by altering fat sources in diets. It should be mentioned that the evaluated fat sources did not cause differences in the performance of the hen or in the egg quality. The decreasing order of nutritional quality of eggs from hens fed diets based on different sources of n-6/n-3 FA is: linseed oil $>$ fish oil>rapeseed oil >sunflower oil.

\section{REFERENCES}

AOAC, 2005. Association of Offiical Analytical Chemist, Official Methods of Analysis. 15th Edition. Washington, DC

Atakisi E., Atakisi O., Yaman H., Arslan I., 2009. Omega-3 fatty acid application reduces yolk and plasma cholesterol levels in Japanese quails. Food Chem. Toxicol. 47, 2590-2593

Ayerza R., Coates W., 2000. Dietary levels of Chia: Influence on yolk cholesterol, lipid content and fatty acid composition for two strains of hens. Poultry Sci. 79, 724-739

Aymond W.M., Van Elswyk M.E., 1995. Yolk thiobarbituric acid reactive substances and n-3 fatty acids in response to whole and ground flaxseed. Poultry Sci. 74, 1388-1394

Baucells M.D., Crespo N., Barroeta A.C., Ferrer S.L., Grashorn M.A., 2000. Incorporation of different poly unsaturated fatty acids into eggs. Poultry Sci. 79, 51-59

Cachaldora P., Garcia-Rebollar P., Alvarez C., De Blas J.C., Mendez J., 2006. Effect of type and level of fish oil supplementation on yolk fat composition and n-3 fatty acids retention efficiency in laying hens. Brit. Poultry Sci. 47, 43-49

Cobos A.L., Delahoz L., Cambero M.I., Ordonez J.A., 1995. Dietary modification and hen strain dependence of egg yolk lipids. Food Res. Int. 28, 71-76

da Silva W.A., Elias A.H.N., Aricetti J.A., Sakamoto M.I., Murakami A.E., Gomes S.T.M., Visentainer J.V., De Souza N.E., Matsushita M., 2009. Quail egg yolk (Coturnix coturnix japonica) enriched with omega-3 fatty acids. Food Sci. Technol. 42, 660-663

Filardi R.S., Junqueira O.M., DE Laurentiz A.C., Casartelli E.M., Rodrigues E.A., Araujo L.F., 2005. Influence of different fat sources on the performance, egg quality, and lipid profile of egg yolks of commercial layers in the second laying cycle. J. Appl. Poultry Res. 14, 258-264 
Frankel E.N., 1984. Lipid oxidation: mechanisms, products and biological significance. J. Amer. Oil Chem. Soc. 61, 1908-1917

Gonzales-Esquera R., Leeson S., 2000. Effect of feeding hens regular or deodorized menhaden oil on production parameters, yolk fatty acid profile and sensory quality of eggs. Poultry Sci. 79, 1597-1602

Grashorn M.A., Steinhilber S., 1999. Effect of dietary fat with different relations between omega-6 and omaga-3 fatty acids on egg quality. In: Proceedings of VIII European Symposium on the Qality of Eggs and Egg Products. Bologna (Italy), pp. 95-100

Hammershoj M., 1995. Effects of dietary fish oil with natural content of carotenoids on fatty acid composition, n-3 fatty acid content, yolk colour and egg quality of hen eggs. Arch. Geflugelk. 59, 189-197

Kochler H.H., Beprse G.E., 1975. Egg flavor quality as affected by fish meals or fish oils in laying rations. Poultry Sci. 54, 881-889

Laca A., Pardes B., Diaz M., 2010. A method of egg yolk fractionation. Characterization of fractions. Food Hydrocolloid. 24, 434-443

Lawlor J.B., Gaudette N., Dickson T., House J.D., 2010. Fatty acid profile and sensory characteristics of table-eggs from laying hens fed diets containing microencapsulated fish oil. Anim. Feed Sci. Tech. 156, 97-103

Liu X., Zhao H.L., Thiessen S., House J.D., Jones P.J.H., 2010. Effect of plant sterol-enriched diets on plasma and egg yolk cholesterol concentrations and cholesterol metabolism in laying hens. Poultry Sci 89, 270-275

Mazalli M.R., Faria D.E., Salvador D., Ito D.T., 2004. A comparison of the feeding value of different sources of fat for laying hens: 2. lipid, cholesterol, and vitamin E profiles of egg yolk. J. Appl. Poultry Res. 13, 280-290

Milinsk M.C., Murakami A.E., Gomes S.T.M., Matsushita M., De Souza N.E., 2003. Fatty acid profile of egg yolk lipids from hens fed diets rich in n-3 fatty acids. Food Chem. 83, 287-292

NRC, 1994. Nutrient Requirements of Poultry. 9th revised Edition. National Academy Press. Washington, DC

Parpinello G.P., Meluzzi A., Sirri F., Tallarico N., Versari A., 2006. Sensory evaluation of egg products and eggs laid from hens fed diets with different fatty acid composition and supplemented with antioxidants. Food Res. Int. 39, 47-52

Pie J.E., Spahis K., Seillan C., 1990. Evaluation of oxidative degradation of cholesterol in food and food ingredients: Identification and quantification of cholesterol oxides. J. Agr. Food Chem. 37, 973-979

SAS, 1996. SAS/STAT® User's Guide, release 6.03 Edition. SAS Institute Inc. Cary, NC

Scheideler S.E., Froning G., Cuppett S., 1997. Studies of consumer acceptance of high omega-3 fatty acid-enriched eggs. J. Appl. Poultry Res. 6, 137-146

Scheideler S.E., Jaroni D., Froning G., 1998. Strain and age effcts on agg composition from hens fed diets rich in n-3 ftty acids. Poultry Sci. 77, 192-196

Simopoulos A.P., 1998. Redefining dietary reference values and food safety. World Rev. Nutr. Diet. $83,219-222$

Souza J.G., Costa F.G.P., Queiroga R.C.R.E., Silva J.H.V., Schuler A.R.P., Goulart C.C., 2008. Fatty acid profile of eggs of semi-heavy layers fed feeds containing linseed oil. Braz. J. Poultry Sci. 10, 37-44

Steel R.G.D., Torrie J.H., 1960. Principles and Procedures of Statistics. McGraw-Hill, New York

Van Elswyk M.E., 1997. Comparison of n-3 fatty acids sources in laying hen rations for improvement of whole egg nutritional quality. A review. Brit. J. Nutr. 78, 61-69 
Van Elswyk M.E., Dawson P.L., Sams A.R., 1995. Dietary menhaden oil influences sensory characteristics and head space volatiles of shell eggs. J. Food Sci. 60, 85-89

Woods V.B., Fearon A.M., 2009. Dietary sources of unsaturated fatty acids for animals and their transfer into meat, milk and eggs: A review. Livest. Sci. 126, 1-20

Yang S.C., Chen K.H., 2001. The oxidation of cholesterol in the yolk of selective traditional chinese egg products. Poultry Sci. 80, 370-375 